\title{
TERÜLETI AUTOKORRELÁCIÓS VIZSGÁLAT A LOCAL MORAN I MÓDSZERÉVEL
}

\author{
(Territorial Autocorrelation Analysis with \\ the Local Moran I Method) \\ TÓTH GÉZA
}

Kulcsszavak:

Local Moran I területi autokorreláció területi statisztika

A Local Moran I módszer a területi autokorreláció vizsgálatának egy új módszere. Újdonsága, hogy nem csupán számértékkel, hanem térinformatikai megjelenitéssel mutatja a területi hasonlóságokat, illetve különbségeket. Cikkünk ezt a módszert néhány hazai példa segítségével mutatja be.

A regionális tudomány egyik alapvető kérdése, hogy egy-egy jelenség adott területegységen való megjelenése mennyire hasonló, illetve különböző a szomszédos területegységek értékeihez képest. A hasonlóságok számszerüsítése alapján a vizsgált jelenség térbeli összefüggésrendszerére, illetve annak jellegére vonatkozó következtetések vonhatók le. Munkánkban a területi autokorreláció vizsgálatának módszerét szeretnénk bemutatni, s használatra ajánlani a hazai kutatóknak, mely ötvözi a térinformatikai szoftverek elemzési lehetöségeit a területi statisztikai módszerrel, és példaként néhány lehetséges felhasználási lehetőségre szeretném a figyelmet felhívni, megjegyezve, hogy a lehetőségek tárháza szinte kimeríthetetlen.

A módszert Luc Anselin vezette be (1995). Anselin szerint a Moran I statisztikának két alapvető eleme van:

1) A térbeli (local) változók területi asszociációját vizsgáló Moran I megmutatja minden egyes területi egységre azon területi egységek kiterjedését, melyek értéke hasonló a vizsgált egységhez, valamint

2) a térbeli változók területi asszociációjának mértéke valamennyi vizsgált egység esetén arányos a területi asszociáció globális mértékével.

$$
L_{i}=f\left(Y_{i}, Y_{i j}\right)
$$

ahol $\mathrm{L}_{\mathrm{i}}$ a helyi változó, $\mathrm{Y}_{\mathrm{i}}$ az $\mathrm{i}$ helyen levő intenzitási változó értéke, és $\mathrm{Y}_{\mathrm{ij}}$ az $\mathrm{i}$ szomszédságában lévő ji-ben tapasztalt érték (Moran 1948).

Más szavakkal a Moran I egy olyan mutató, amely megmutatja, hogy a vizsgált terület értéke mennyiben hasonlít vagy különbözik szomszédjától. Ehhez két dolog szükséges. Az első az, hogy minden egyes vizsgálati terület vonatkozásában a szomszédság definiálva legyen. Ennek több lehetséges módja van. Az egyik megoldást az jelenti, hogy a vizsgált egységek tekintetében egy szomszédsági mátrixot állítunk össze, és annak adataival számolunk. Ebben az esetben tehát csak az egymás közti távolság a fontos, s nem kell a pontos koordináták ismerete. Úgy is meg 
lehet viszont oldani a számítást, hogy pontelemzést végzünk, melyben az egyes egységeket pontokhoz kötjük. Így tehát fontos, hogy az adatok aggregálva legyenek településenként, illetve más egységenként. Ekkor megtehetö az, hogy az egyes pontok $\mathrm{x}$ és y koordinátáját használjuk fel a szomszédság meghatározásához.

A vizsgálati egységek lehetnek vagy szomszédos területek, zónák, vagy minden olyan terület, melynek értékét a távolság növekedésével csökkenő súllyal vesszük figyelembe. A csökkenés mértékének meghatározása kutatói feladat, elemzésenként más és más lehet.

A Local Moran I megmutatja a vizsgált terület viszonyát szomszédjaival. Így azokon a területeken, melyek szomszédságában magas intenzitási értékek vannak a Moran I megmutatja, vajon a vizsgált területen ez hasonló (vagyis hasonlóan magas), vagy különböző (alacsony), és fordítva.

\section{A Local Moran I statisztika definiciója}

Anselin (1995) alkalmazott a területi autokorreláció számszerüsítésére egy koncepciót. Az egyik leggyakrabban használatos ebböl a Local Moran I statisztika, amely a Moran féle I statisztika alkalmazása a területi autokorreláció területén.

Íme az I definíciója (Getis-Ord 1996):

$$
I_{i}=\frac{\left(Z_{i}-\bar{Z}\right)}{S_{z}^{2}} * \sum_{j=1}^{N}\left[W_{i j} *\left(Z_{j}-\bar{Z}\right)\right]
$$

ahol a $\bar{Z}$ valamennyi egység átlaga, $Z_{\mathrm{j}}$ az i egység értéke, $\mathrm{Z}$ j valamennyi (az $\mathrm{i}-\mathrm{n}$ kívüli) területegység értéke, $\mathrm{j}(\mathrm{ahol} \mathrm{j} \neq \mathrm{i}), \mathrm{S}_{\mathrm{z}}{ }^{2}$ valamennyi vizsgált egység változójának szóródása, és $W_{\mathrm{ij}}$ az i és a j egységek közötti távolsági súlytényező (amely, mint fentebb említettuk, származhat $\mathrm{W}_{\mathrm{ij}}$ szomszédsági mátrixból, illetve a j és i pontok x és y koordinátáján alapuló távolsági adatokból).

Ilyen esetben az I definíciója máshogy is elképzelhető (Anselin 1995):

$$
I_{i}=p_{i} \sum W_{i j} p_{j}
$$

Ebben az esetben a $p_{i}$ a változó különbségét jelenti i terület és az átlag között, $W_{i j}$ egy súlytényező, amely az i és j terület közötti kapcsolat erősségére utal. A súlytényezö biztosítja, hogy a p p-nek csak azon értékeit vegyük számításba, amelyek szomszédosak. $A p_{j}$ ez esetben természetesen szintén a jérték átlagtól való eltérését jelenti.

\section{Távolsági súlytényezök}

A súlytényező egyrészt lehet egy szomszédossági indikátor, melynek értéke 1, amennyiben egy terület, zóna egy másikkal szomszédos, illetve 0 , amennyiben nem szomszédosak. Másrészt a súlytényező lehet távolságfüggö is, mely csökken az i és j területek közötti távolság növekedésével. Szomszédossági indexet használunk, ha 
csak a közeli szomszédsággal számolunk, ilyenkor ugyanis azok hatását súllyal vesszük figyelembe, és más területeknek nincs súlyuk. A távolsági súlyokat alkalmazzuk a területi interakciók definiálására, amikor a vizsgált területegységtől távolabb fekvő területeknek is lehet hatásuk az adat lokális értékére.

Jelen elemzésünkben az alábbi távolsági súlytényezővel számoltunk:

$$
W_{i j}=\frac{1}{d_{i j}}
$$

ahol a $\mathrm{d}_{\mathrm{ij}}$ a vizsgált $\mathrm{i}$ területegység és egy másik $\mathrm{j}$ terulet közötti távolság.

\section{Módosítás kis távolságok esetén}

A használt mértékegységektöl függöen problematikus lehet a távolsági súlyok kiszámítása abban az esetben, ha a távolság $1(\mathrm{~km}, \mathrm{~m}$ stb.) alá kerül. Ebben az esetben ugyanis a távolság csökkenésével a súly növekszik. Ennek kivédésére alkalmaztunk egy korrekciós tényezöt, mely szerint a maximális súly sohasem lehet nagyobb, mint 1 .

A korrekciós tényező a következő:

$$
W_{i j}=\frac{1 k m}{1 k m+d_{i j}}
$$

A mértékegység természetesen más is lehet ( $\mathrm{m}, \mathrm{dm}$ stb.).

A megkapott Local Moran I értéket több más eljáráshoz hasonlóan érdemes standardizálni, melynek segítségével a torzító hatások jobban kiszürhetők. Ilyen torzító hatás lehet egyfelöl az, ha faktoranalízis eredményeként megkapott mutatót igyekszünk térben elemezni. A cél ekkor a különböző mértékegységekből fakadó torzító hatások kiszürése lehet. Másrészt különösen nagy szórású változó esetén érdemes figyelembe venni a standardizált értéket.

$$
Z\left(I_{i}\right)=\left[I_{i}-E\left(I_{i}\right)\right] / S\left(I_{i}\right)
$$

ahol $\mathrm{Z}\left(\mathrm{I}_{\mathrm{i}}\right)$ a standardizált változó, $\mathrm{I}_{\mathrm{i}}$ az eredeti változó, $\mathrm{E}\left(\mathrm{I}_{\mathrm{i}}\right)$ az eredeti változó átlaga, $S\left(I_{i}\right)$ az eredeti változó szórása.

Összességében megállapítható, hogy a Local Moran statisztika alkalmas arra, hogy kimutassa azokat a területeket, amelyek hasonlóak, illetve különbðzöek a szomszédjaiktól. A felhasználó munkája során a Local Moran eredményét összevetheti az abszolút adatokkal annak érdekében, hogy meg tudja vizsgálni, a nagyfokú hasonlóság vajon a változó magas vagy alacsony értékeinek koncentrációja, és fordítva. A Local Moran I értéke minél nagyobb, annál szorosabb a térbeli hasonlóság. Negatív érték esetén viszont megállapítható, hogy a változók térbeli eloszlása a véletlenszerühöz közelít, $\mathrm{s}$ az elemzést ezt figyelembe véve lehet megtenni. 


\section{Gyakorlati példák a Local Moran felhasználására}

A területi fejlettség egyik leggyakrabban használt mutatója az egy före jutó személyi jövedelemadó (1., 2., 3. ábra). A mutatónak természetesen vannak bizonyos hiátusai, $\mathrm{s}$ így bizonyos vállalkozások nem kerülnek bele (pl. kisebb mezögazdasági vállalkozások, melyek adómentességet élveznek), de természetesen arra is utalni lehet, hogy sok esetben a szürke és fekete gazdaságba húzódó cégek miatt az ilyen irányú fejlettségi vizsgálat nem lehet pontos. A módszert ez esetben elsösorban a főbb nagytérségi összefüggések bemutatására érdemes használni.

\section{1. ÁBRA}

Egy före jutó szja, 2000

(Income Tax per Capita, 2000)

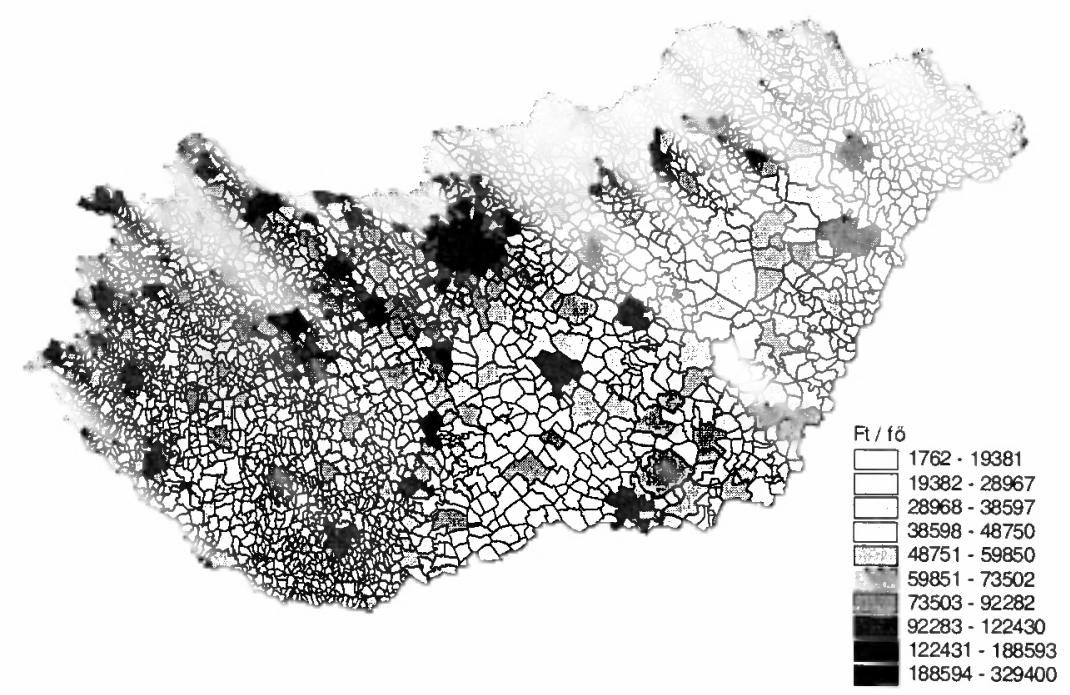

Forrás: Saját szerkesztés.

A Local Moran I segítségével bemutatható, hogy a legmagasabb területi autokorrelációval jellemezhető területek Budapest és agglomerációja, valamint az Észak-Dunántúl tekintetében határolhatók le. E térségek egyértelmüen hot-spotnak tekinthetök, vagyis magas értékekkel rendelkeznek. Viszonylag magas területi autokorrelációval jellemezhetö területek láthatóak az északkelet-magyarországi, illetve a dél-dunántúli határ menti perifériákon. E településcsoportokról viszont egyértelmüen megállapítható, hogy cold-spotok, vagyis itt zömmel alacsony értékekkel jellemezhető települések tömörülnek. Több helyen az egységes tömbböl néhány település tünik ki alacsony autokorrelációval. Ilyen például: Budakeszi, valamint Pécs, Kaposvár, Nyíregyháza, illetve Debrecen. Az első esetben a környezeténél alacsonyabb, míg a többinél jóval magasabb egy före jutó szja értékkel találkozunk. Mind a Local Moran I, mind pedig az egy före jutó szja értékei azt mutatják, hogy az országon belül a változó legnagyobb szóródása az Észak- 
Tér és Társadalom 17. évf. 2003/4. 39-49. p.

Dunántúl nyugati részén látható, itt az alacsony és a magas egy főre jutó szja értékek szinte településröl-településre változnak. Némileg kisebb változékonyság jellemzi az Alföld településeit, és autokorrelációjuk országos szinten meglehetỏsen alacsony.

\section{2. ÁBRA}

Egy före jutó szja Local Moran I-je, 2000 (Local Moran I of Income Tax per Capita, 2000)

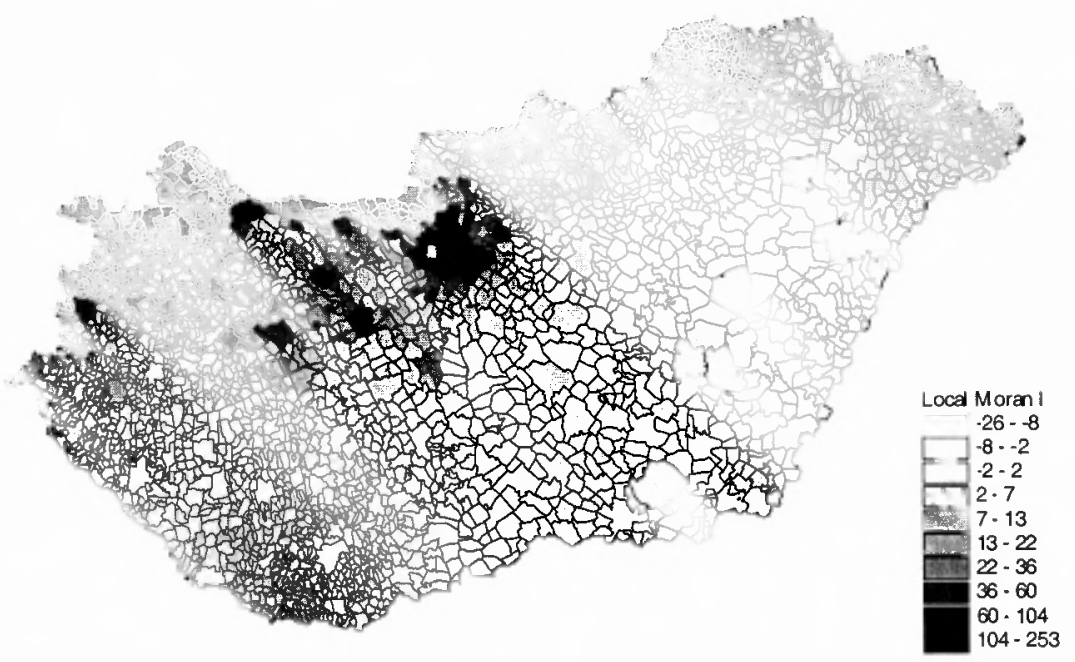

Forrás: Saját szerkesztés.

\section{3. ÁBRA}

Egy före jutó szja standardizált Local Moran I-je, 2000 (Standardized Local Moran I of Income Tax per Capita, 2000)

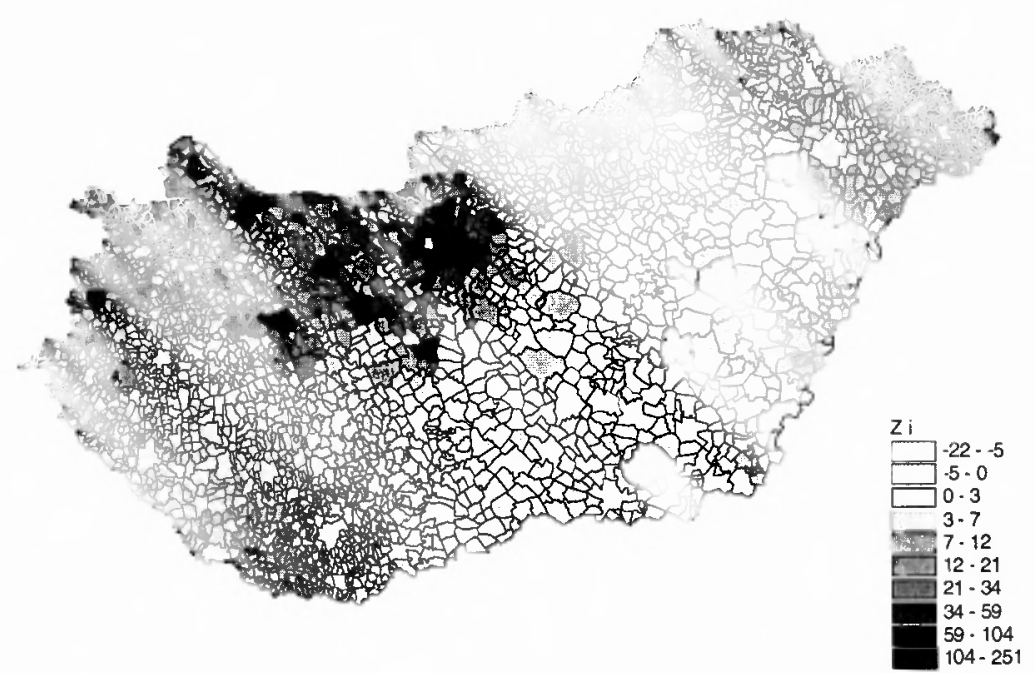

Forrás: Saját szerkesztés. 
Az önkormányzati mérlegekböl a helyi adókat, illetve annak egy lakosra jutó részét választottuk elemzésünk további tárgyául (4., 5., 6. ábra). Ez esetben a cél már lehet kisebb összefüggésrendszerek bemutatása is, hiszen az adatok szóródása meglehetősen nagy. Sajnálatos módon a helyi adókra nem állt rendelkezésre bontott állomány, melyben külön tudtam volna kezelni az iparüzési, idegenforgalmi, illetve a kommunális adók tételeit. Így sajnos a kép kissé árnyalt, de több fontos megállapítás megtételére elégséges.

Az egy före jutó helyi adók tekintetében a legmagasabb autokorrelációt a Balaton partján, valamint Budapest, illetve környéke vonatkozásában figyelhetjük meg. A magas autokorrelációt e területeken egyértelmủen a magas egy före jutó helyi adók okozzák. Ezek nagy valószínüség szerint az első esetben az idegenforgalmi, míg a többiben az iparüzési adóhoz kötődnek.

Magas autokorrelációval jellemezhetö területeket láthatunk még a Dunántúliközéphegység néhány településén is: Ajka, Herend, Veszprém. Ezek Local Moran I értéke magas ugyan, de ez esetben - bár a közvetlen környezetükkel magas az autokorrelációjuk - az egy lakosra jutó helyi adójuk jóval magasabb a tágabb környezetüknél.

Szabolcs-Szatmár-Bereg megye települései közepes autokorrelációt mutatnak, s csak néhány település: Kisvárda, Mátészalka, Záhony, Tuzsér stb. emelkedik a környezete fölé. A Dél-Dunántúl településein az elöbbinél némileg alacsonyabb autokorreláció mellett az egy fỏre jutó helyi adók mértéke is alacsony.

Az szja vizsgálatához hasonlóan az Alföld viszonylag alacsony korreláltságú települései közül itt is kitünnek a megyei jogú városok: Nyíregyháza, Debrecen, melyek mellett érdemes felhívni a figyelmet Hajdúszoboszló és környéke helyzetére. E településcsoport egy lakosra jutó helyi adó vonatkozásában kiemelkedik a környezete fölé.

A Local Moran I segítségével több esetben egyes döntések magyarázata is megtehetô. Erre példa Berente esete, mely hosszú ideig próbálkozott kiválni Kazincbarcikából. Az 1999-es kiválás egyik fỏ magyarázataként fogható fel, hogy országos szinten a legalacsonyabb autokorrelációt Berente esetében láthatjuk, vagyis a környezetétỏl e település ütött el a legnagyobb mértékben. Ennek oka, hogy a kis lakosság mellett itt különösen nagy helyi adót (iparúzési adó - Borsodchem) szednek be, mely az egész térségben kiemelkedö. Vagyis a településnek elemi érdeke volt a leválás, s így jóval nagyobb helyi adóval tud gazdálkodni, mintha Kazincbarcikával osztozkodna.

A környezetétől hasonlóan nagy mértékben a Borsod-Abaúj-Zemplén megyei Becskeháza, valamint a Baranya megyei Alsómocsolád tér el. Mind a két település halmozottan hátrányos helyzetủ térségben található, s tỏlük eltérően a helyi adottságoknak köszönhetỏen az országos átlag többszörösét tudták beszedni egy före vetítve. 
Tér és Társadalom 17. évf. 2003/4. 39-49. p.

\section{4. ÁBRA}

Egy lakosra jutó helyi adók, 2001

(Local Taxes per Capita, 2001)

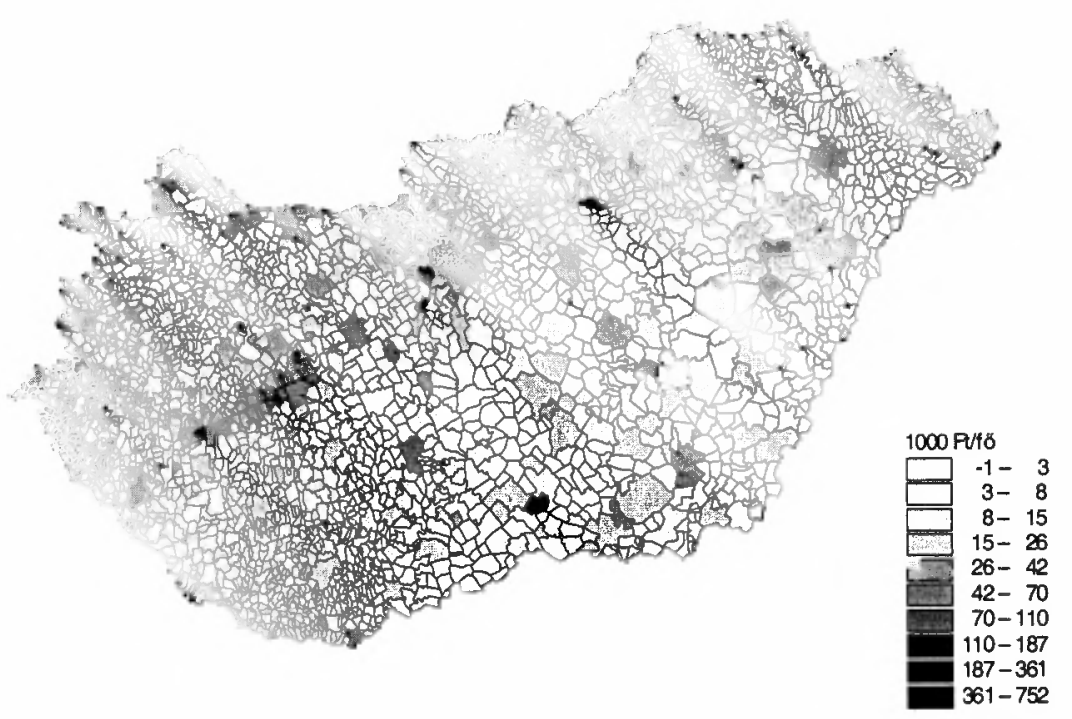

Forrás: Saját szerkesztés.

\section{5. ÁBRA}

Egy lakosra jutó helyi adók Local Moran 1-je, 2001

(Local Moran I of Local Taxes per Capita, 2001)

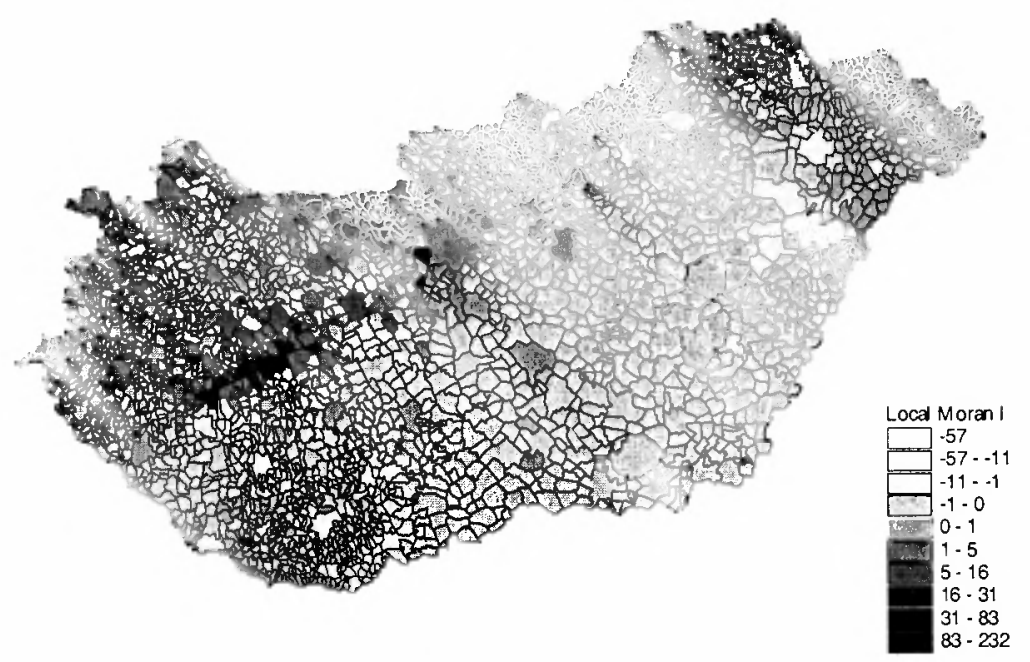

Forrás: Saját szerkesztés. 


\section{6. ÁBRA}

Egy lakosra jutó helyi adók standardizált Local Moran I-je, 2001

(Standardized Local Moran I of Local Taxes per Capita, 2001)

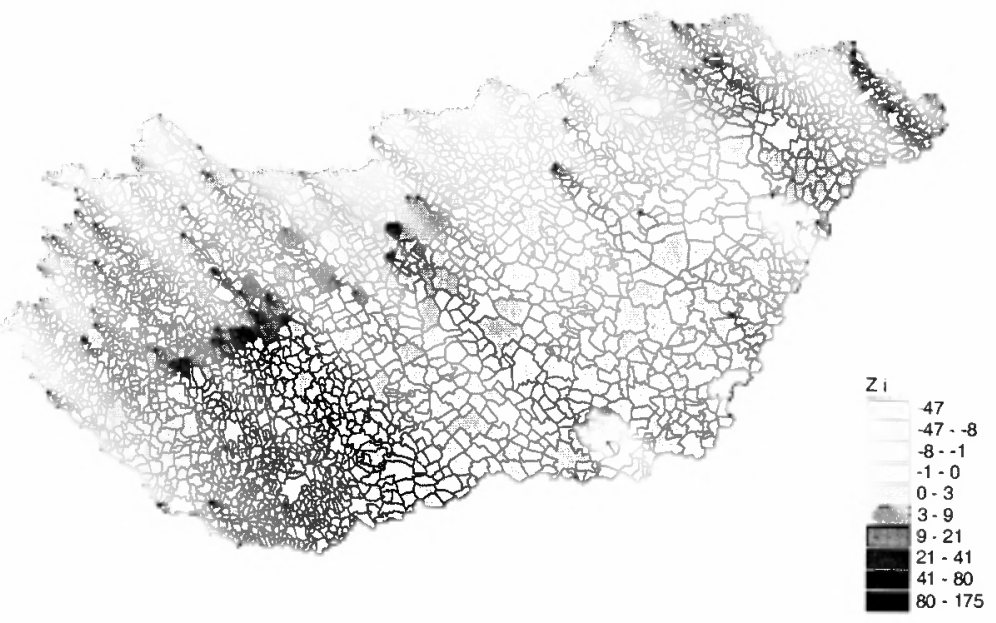

Forrás: Saját szerkesztés.

Az eddigiektöl kissé eltér a regisztrált munkanélküliek számának változása (7., 8., 9. ábra). Mint az abszolút adatokat ábrázoló térképen látható, a szórás nagyon nagy, s elsősorban a megyeszékhelyeken, illetve a nagyobb városokban csökkent a regisztrált munkanélküliek száma, míg a legjobban Hajdúhadházon, Tiszakarádon és Gyürén növekedett.

\section{7. ÁBRA}

Regisztrált munkanélküliek számának változása, 1997-2001

(Change in the Number of Registered Unemployed, 1997-2001)

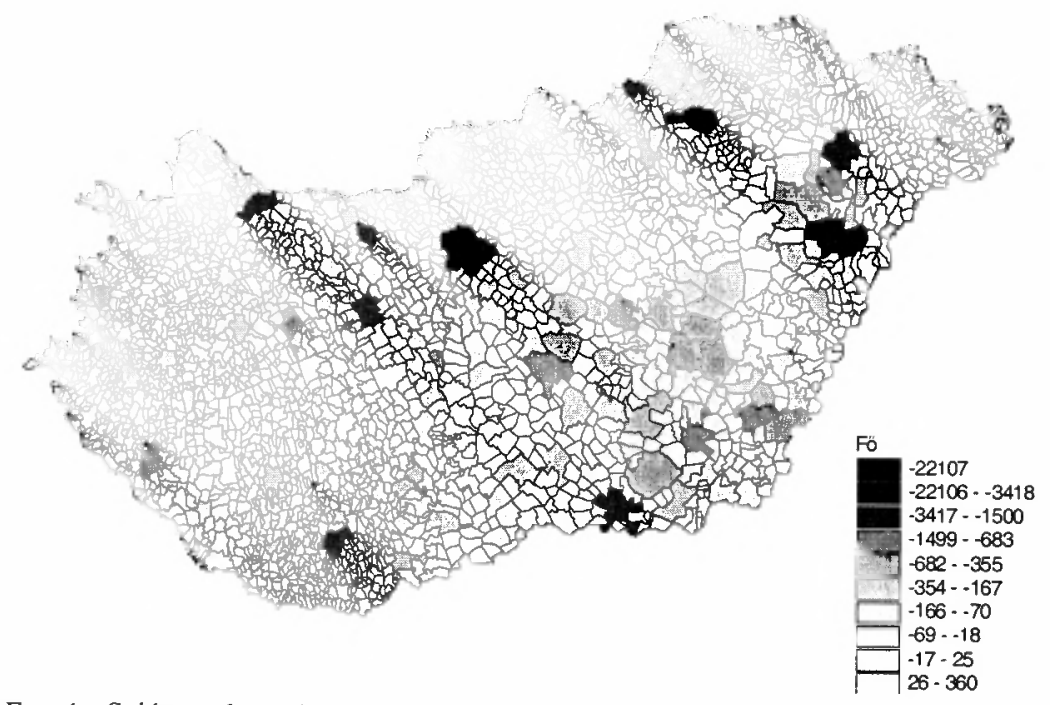

Forrás: Saját szerkesztés. 
Magas területi autokorrelációt elsősorban a főváros és környéke, Debrecen és Nyíregyháza (Hajdúhadházat kivéve), Tatabánya, Cegléd-Szolnok-Törökszentmiklós, Kecskemét, Szeged, illetve Békéscsaba környékén láthatunk. Ezekben a településcsoportokban az átlagosnál nagyobb volt a munkanélküliek csökkenése. A Dunántúl területi autókorrelációja viszonylag alacsony, s kiemelkednek belőle a jelentősebb központok: Sopron, Szombathely, Zalaegerszeg, Kaposvár stb., ahol az átlagosnál nagyobb csökkenés zajlott.

\section{8. ÁBRA}

Regisztrált munkanélküliek számának változása, 1997-2001 (Local Moran I) (Change in the Number of Registered Unemployed, 1997-2001, Local Moran I)

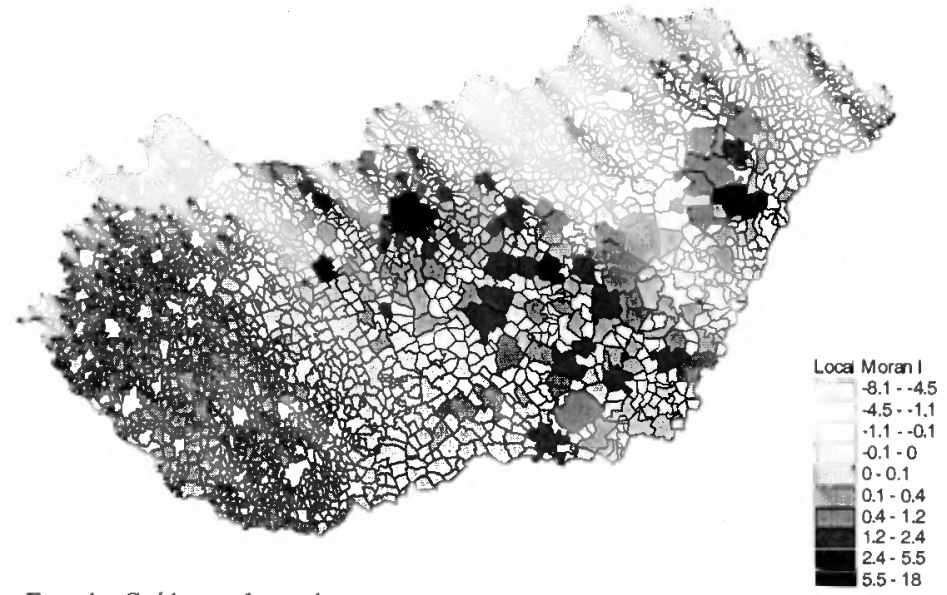

Forrás: Saját szerkesztés.

\section{9. ÁBRA}

Regisztrált munkanélkiliek számának változása, 1997-2001 (Standardizált Local Moran I) (Change in the Number of Registered Unemployed, 199-2001, Standardized Local Moran I)

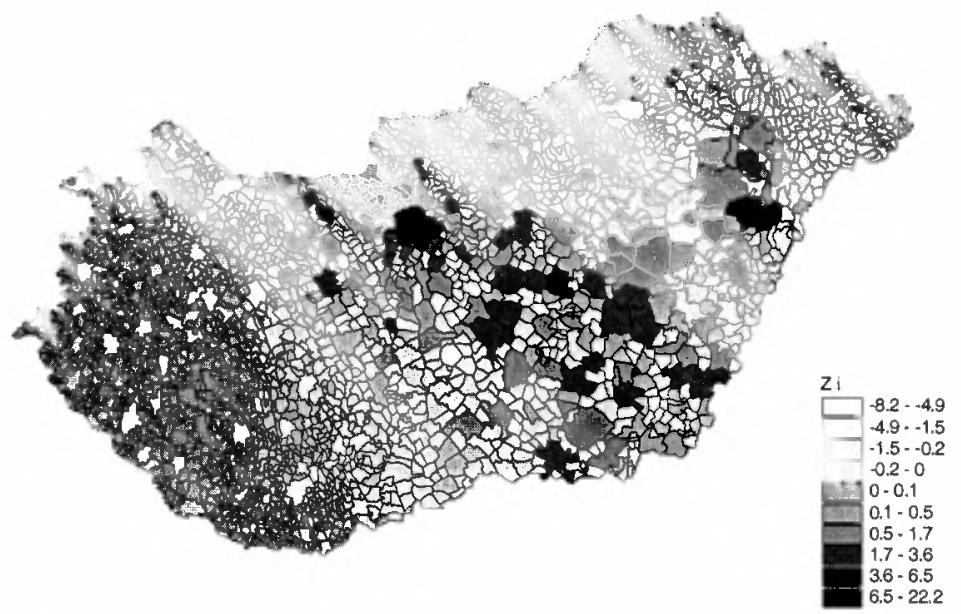

Forrás: Saját szerkesztés. 


\section{Összefoglalás}

Mint látható, a Local Moran I értéke más területi autokorrelációs mutatókkal ellentétben nem 1 és -1 között változik, s értelmezése nem önállóan, hanem elsősorban térképi környezetben képzelhetö el.

A Local Moran I alkalmazása elsősorban más területi vizsgálatokat kiegészítö, azokat támogató módszerként indokolt. Segítségével elkülöníthetők olyan településcsoportok folyamatai, melyeket sok esetben, más összefüggés-rendszerben vizsgálnánk, gondolok itt a kistérség, illetve megyehatárokat átlépö, s így együttesen nehezen vizsgálható település-együttesekre. Ilyen esetekben a módszernek térbeli összefüggések kimutatásában és az összetartozó településcsoportok lehatárolásában fontos szerepe lehet. Ilyen lehatárolások elképzelhetök a fejlettségi vizsgálatoknál a centrum-periféria vonatkozásában, de a felhasználó-beszállító kapcsolatrendszerben, vagy más kapcsolatrendszerben is.

További lehetőségeket jelent azonos homogén csoportok kimutatásában, melyek más változók vonatkozásában nem képeznének egységes rendszert. Ilyen kapcsolatokat láthatunk bizonyos büncselekmények térbeli megjelenése tekintetében is, ilyenkor ugyanis olyan területek szoros kapcsolatára, illetve a kapcsolat hiányára lehet rámutatni, melyek esetleg közigazgatási szempontból, vagy más tekintetben nem tartoznak össze. İgy a hatósági döntéshozatalt néhány konkrét összefüggésben tudja támogatni a Local Moran I.

Alkalmazása kiegészítéséhez érdemes más területi autokorrelációs mutatókat is igénybe venni. A módszer legnagyobb elönye, hogy bármilyen társadalmigazdasági jelenség, folyamat elemzéséhez, térbeli összefüggésrendszerének feltérképezéséhez komoly segítséget biztosít, mivel nem csak számszerúsíti a korreláció mértékét, hanem a térinformatika segítségével azt térben is bemutatja.

\section{Irodalom}

Anselin, L. (1995) Local indicators of spatial association-LISA. - Geographical Analysis. 2. 93-115. o. Getis, A.-Ord, J.K. (1996) Local spatial statistics: an overview. - Longley, P.-Batty, M. (eds.) Spatial Analysis: Modelling in a GIS Environment. GeoInformation International, Cambridge. 261-277. o.

Moran, P.A.P. (1948) J. Roy. Stat. Soc. ser. B 10. 


\section{TERRITORIAL AUTOCORRELATION ANALYSIS WITH THE LOCAL MORAN I METHOD}

\section{GÉZA TÓTH}

The application of the Local Moran I is primarily reasonable as a complementary and supporting methodology of other territorial analyses. With its application we can separate different processes of settlement groups, of which in many instances we analysed in another context. We mean here especially those settlement groups, which have members from different neighbour micro regions or counties that makes difficult the analysis of the groups. In such cases this methodology can play important role in demonstrating of territorial relationships and locating coherent settlement groups. These are especially useful for development examinations (centre-periphery aspects) and applier-supplier relationships or other contexts. 